\title{
PENGARUH STRUKTUR MODAL DAN PERTUMBUHAN PERUSAHAAN TERHADAP NILAI PERUSAHAAN DENGAN PROFITABILITAS SEBAGAI VARIABEL INTERVENING
}

(Studi Empiris pada Perusahaan Pertambangan yang Terdaftar di Bursa Efek Indonesia 2013-2017)

\author{
Fitri Amelia ${ }^{1}$, M. Anhar ${ }^{2}$ \\ PT. Sylva Prakarsa ${ }^{1}$ \\ Jl. Letjend Suprapto, Komplek Ruko Mega Grosir Cempaka Mas, Jakarta ${ }^{1}$ \\ Program Studi Akuntansi ${ }^{2}$ \\ Sekolah Tinggi Ilmu Ekonomi Indonesia Jakarta Indonesia \\ fitriamelia.c105@gmail.com
}

\begin{abstract}
Abstrak - Tujuan dari penelitian ini adalah untuk mengetahui apakah Struktur Modal dan Pertumbuhan Perusahaan mempengaruhi secara signifikan Nilai Perusahaan dengan Profitabilitas sebagai variabel intervening pada Perusahaan pertambangan yang Terdaftar di Bursa Efek Indonesia 2013-2017. Struktur Modal diproksi menggunakan Debtto-Equity Ratio (DER), Pertumbuhan Perusahaan diproksi menggunakan perhitungan Perubahan Total Aktiva, Profitabilitas diproksi menggunakan Return On Equity (ROE) dan Nilai Perusahaan diproksi menggunakan Price to Book Value (PBV). Dengan menggunakan teknik purposive sampling, sampel yang digunakan pada penelitian ini berjumlah 33 perusahaan dari populasi yang berjumlah 41 perusahaan dan periode penelitian berjumlah 5 tahun. Penelitian kausal-komparatif ini menggunakan data panel dengan teknik pengumpulan data secara dokumentasi atau arsip dari Indonesian Capital Market Electronik Library. Teknik analisis dalam penelitian ini menggunakan Path Analysis. Penelitian ini menunjukkan hasil bahwa Struktur Modal berpengaruh signifikan terhadap Profitabilitas dan Nilai Perusahaan, Pertumbuhan Perusahaan tidak berpengaruh signifikan terhadap Profitabilitas dan Nilai Perusahaan dan Profitabilitas tidak berpengaruh signifikan terhadap Nilai Perusahaan. Kemudian Profitabilitas tidak mampu memediasi pengaruh Struktur Modal terhadap Nilai Perusahaan, namun mampu memediasi pengaruh Pertumbuhan Perusahaan terhadap Nilai Perusahaan
\end{abstract}

Kata kunci komponen; Nilai Perusahaan, Struktur Modal, Pertumbuhan Perusahaan, Profitabilitas, Price to Book Value, Debt-toEquity Ratio, Perubahan Total Aktiva, Return On Equity, Analisis Jalur 


\section{PENDAHULUAN}

Tahun 2015 merupakan tahun yang buruk bagi sektor pertambangan. Perusahaan pertambangan global terbesar mencatat kerugian bersih kolektif (US\$27 miliar), dan merupakan yang pertama dalam sejarah di mana kapitalisasi pasar turun sebesar $37 \%$. Penurunan tersebut bahkan telah secara efektif menghapus keuntungan yang diperoleh selama siklus super komoditas. Perusahaan pertambangan berupaya keras meningkatkan produktivitas, diikuti dengan pelepasan aset atau penutupan usaha yang mempengaruhi Pertumbuhan Perusahaan dari sudut pandang perubahan asset. Pemegang saham bersikeras untuk fokus pada investasi jangka pendek, yang berdampak pada ketersediaan modal untuk diinvestasikan dan mengakibatkan terbatasnya opsi untuk pertumbuhan, sehingga perusahan-perusahaan pertambangan mencari sumber dana lain yang dapat menopang bisnis mereka yakni melalui hutang, yang membuat proporsi hutang di dalam Struktur Modal mereka meningkat.

Kondisi kinerja perusahaan dari profitabilitas perusahaan-perusahaan di sektor pertambangan pada tahun 2015 adalah yang terburuk, namun di tahun 2016 mampu bangkit kembali meskipun 2017 mengalami penurunan. Debt-to-Equtiy Ratio (DER) tahun 2015 merupakan angka yang tertinggi dibandingkan yang lainnya. Pertumbuhan Perusahaan mengalami penurunan dari 2013 sampai dengan tahun 2016, kemudian meningkat kembali pada tahun 2017. Price to Book Value (PBV) 2015 merupakan yang terendah, PBV rendah dapat mengindikasikan menurunnya kualitas dan kinerja fundamental emiten (undervalued), namun meski begitu PBV yang undervalued dinilai sangat baik untuk investasi jangka panjang.

Perusahaan pertambangan di Indonesia terus berfokus pada produktivitas dan pengurangan biaya yang mengakibatkan penurunan biaya operasi sebesar $17 \%$ di tengah peningkatan volume produksi dan rendahnya biaya masukan dan hal ini diharapkan dapat menjaga kinerja perusahaan melalui Profitabilitas. Perusahaan pertambangan juga mulai fokus pada disiplin modal dan juga melakukan pengurangan asset melalui pelepasan asset dan penundaan beberapa proyek marginal, demi memaksimalkan Nilai Perusahaan. Hasilnya pada tanggal 30 April 2016, kapitalisasi pasar perusahaan pertambangan yang tercatat di BEI meningkat sebesar 23\% menjadi 198 triliun Rupiah 
yang sejalan dengan kenaikan harga sejumlah komoditas selama empat bulan pertama tahun 2016, dan perbaikan keyakinan investor terhadap sektor pertambangan Indonesia.

Tujuan perusahaan adalah untuk memaksimalkan nilai perusahaan dan mensejahterakan para pemegang saham. Bagi investor, nilai perusahaan merupakan konsep penting karena nilai perusahaan merupakan indikator bagaimana pasar menilai perusahaan secara keseluruhan. Nilai Perusahaan (yang sering dikaitkan dengan harga saham) merupakan persepsi investor terhadap tingkat keberhasilan perusahaan. Salah satu pendekatan dalam menentukan nilai intrinsik saham adalah price book value (PBV). Nilai perusahaan yang tinggi akan membuat pasar percaya tidak hanya pada kinerja perusahaan saat ini namun pada prospek perusahaan dimasa yang akan datang.

Penelitian terdahulu telah dilakukan untuk mengukur dan mengetahui bahwa struktur modal, pertumbuhan perusahaan, dan profitabilitas perusahaan memiliki pengaruh yang signifikan terhadap nilai perusahaan. Dengan bertujuan untuk meningkatkan kekayaan pemilik perusahaan yang sering dinilai melalui nilai perusahaan, hal ini dapat membuktikan bahwa pentingnya struktur modal, pertumbuhan perusahaan, dan profitabilitas dalam menentukan nilai perusahaan. Berdasarkan penelitian-penelitian sebelumnya di atas maka dalam penelitian ini digunakan variabel penelitian seperti struktur modal, pertumbuhan perusahaan, profitabilitas, dan nilai perusahaan.

\section{KAJIAN TEORI}

Nilai Perusahaan. Nilai perusahaan merupakan persepsi investor terhadap tingkat keberhasilan perusahaan yang terkait erat dengan harga sahamnya. Harga saham yang tinggi membuat nilai perusahaan juga tinggi, dan meningkatkan kepercayaan pasar tidak hanya terhadap kinerja perusahaan saat ini namun juga pada prospek perusahaan di masa mendatang. Harga saham yang digunakan umumnya mengacu pada harga penutupan (closing price), dan merupakan harga yang terjadi pada saat saham diperdagangkan di pasar (Hermuningsih, 2013).

Dalam Hermuningsih (2013) dijelaskan bahwa nilai perusahaan adalah sangat penting karena dengan nilai perusahaan yang tinggi akan diikuti oleh tingginya kemakmuran pemegang saham. Tujuan yang ingin dicapai manajemen keuangan adalah maksimalisasi kesejahteraan pemilik perusahaan atau maksimalisasi nilai perusahaan. 
Bagi perusahaan terbuka (go-public), indikator nilai perusahaan tercermin pada harga saham yang diperdagangkan di pasar modal, karena seluruh keputusan keuangan akan terefleksi di dalamnya. Pengambilan keputusan investasi, pendanaan maupun kebijakan dividen yang buruk mengakibatkan para investor bereaksi dan membuat harga pasar saham menjadi turun. Sebaliknya, mereka akan bereaksi dan membuat naik harga saham di pasar karena adanya suatu kebijakan perusahaan yang dianggap baik. Sehingga, berdasarkan tujuan ini maka keputusan yang baik adalah keputusan yang mampu menciptakan kesejahteraan para pemegang saham, di samping mempertimbangkan berbagai masalah keuangan lain yang dihadapi perusahaan (Halim, 2015).

Menurut Husnan (2000) nilai perusahaan merupakan harga yang bersedia dibayar oleh calon pembeli apabila perusahaan tersebut dijual. Sedangkan menurut Keown (2004) nilai perusahaan merupakan nilai pasar atas surat berharga hutang dan ekuitas perusahaan yang beredar. Menurut Brigham \& Houston (2001) terdapat beberapa pendekatan analisis rasio dalam penilaian market value, terdiri dari pendekatan Price Earning Ratio (PER), Price Book Value Ratio (PBVR), Market Book Ratio (MBR), Deviden Yield Ratio, dan Dividend Payout Ratio (DPR). Menurut Brigham dan Gapenski (2006) dalam Hermuningsih (2013) nilai perusahaan dapat diukur dengan price to book value (PBV), yaitu perbandingan antara harga saham dengan nilai buku per saham.

Dalam penelitian ini nilai perusahaan diukur dengan PBV. Rasio harga saham terhadap nilai buku perusahaan atau price book value (PBV), menunjukkan tingkat kemampuan perusahaan menciptakan nilai relatif terhadap jumlah modal yang diinvestasikan. PBV yang tinggi mencerminkan harga saham yang tinggi dibandingkan nilai buku perlembar saham. Semakin tinggi harga saham, semakin berhasil perusahaan menciptakan nilai bagi pemegang saham. Keberhasilan perusahaan menciptakan nilai tersebut tentunya memberikan harapan kepada pemegang saham berupa keuntungan yang lebih besar pula (Sartono, 2010).

Price to Book Value Ratio merupakan rasio yang menunjukkan hasil perbandingan antara harga pasar per lembar saham dengan nilai buku per lembar saham. Rasio ini digunakan untuk mengukur tingkat harga saham apakah overvalued atau undervalued. Semakin rendah nilai PBV suatu saham maka saham tersebut 
dikategorikan undervalued, di mana sangat baik untuk investasi jangka panjang. Namun, rendahnya nilai PBV juga dapat mengindikasikan menurunnya kualitas dan kinerjal fundamental emiten. Rasio ini dihitung dengan formula sebagai berikut (Hery, 2016):

$$
P B V=\frac{\text { Harga per Lembar Saham }}{\text { Nilai Buku per Lembar Saham }} \times 100 \%
$$

Nilai Buku per Lembar Saham digunakan untuk mengukur nilai shareholders equity atas setiap saham, dan besarnya dihitung dengan cara membagi total shareholders equity dengan jumlah saham yang beredar (Robert, 1997).

Struktur Modal. Ada beberapa pengertian struktur modal. Dalam Fahmi (2014) dikatakan bahwa Capital structure or the capitalization of the firm is the permanent financing represented by long-term debt, preferred stock and shareholder's equity. Capital structure (struktur modal) adalah komposisi saham biasa, saham preferen, dan berbagai kelas seperti itu, laba yang ditahan, dan utang jangka panjang yang dipertahankan oleh kesatuan usaha dalam mendanai aktiva (Fahmi, 2015). Struktur modal merupakan gambaran dari bentuk proporsi finansial perusahaan yaitu antara modal yang dimiliki yang bersumber dari utang jangka panjang (long-term liabilities) dan modal sendiri (shareholder's equity) yang menjadi sumber pembiayaan suatu perusahaan, dan struktur modal suatu perusahaan terdiri dari long-term debt dan shareholder's equity, dimana stockholder equity terdiri dari preferred stock dan common equity, dan common equity itu sendiri adalah terdiri dari common stock dan retained earnings (Fahmi, 2015).

Struktur modal bertujuan memadukan sumber dana permanen yang selanjutnya digunakan perusahan dengan cara yang diharapkan akan mampu memaksimumkan nilai perusahaan. Bagi sebuah perusahaan sangat dirasa penting untuk memperkuat kestabilan keuangan yang dimilikinya, karena perubahan dalam struktur modal diduga bisa menyebabkan perubahan nilai perusahaan. Turunnya nilai perusahaan bisa mempengaruhi pada turunnya nilai saham perusahaan tersebut. Nilai perusahaan diperoleh dari hasil kualitas kinerja suatu perusahaan khususnya kinerja keuangan (financial performance), tentunya tidak bisa dikesampingkan dengan adanya dukungan dari kinerja non keuangan juga, sebagai sebuah sinergi yang saling mendukung pembentukan nilai perusahaan. Melakukan analisa struktur modal dianggap suatu hal 
yang penting karena dapat mengevaluasi risiko jangka panjang dan prospek dari tingkat penghasilan yang didapatkan perusahaan selama menjalankan aktivitasnya.

Struktur modal perusahaan akan berubah dari waktu ke waktu sesuai dengan kondisi perusahaan. Manajemen sebaiknya memiliki struktur modal yang spesifik untuk mengatasi ketidakpastian lingkungan bisnis. Manajemen akan meningkatkan jumlah hutang jika hutang saat ini masih dibawah tingkat hutang sasaran. Manajemen akan meningkatkan ekuitas apabila rasio hutang berada diatas tingkat sasaran. Komposisi hutang dan modal perusahaan di dalam struktur modal dapat diukur berdasar dua rasio yaitu total debt ratio dan debt to equity ratio (Ross et al., 2010).

Secara matematis DER dapat dirumuskan sebagai berikut (Robert, 1997):

$$
D E R=\frac{\text { Total Hutang }}{\text { Total Ekuitas }} \times 100 \%
$$

Pertumbuhan Perusahaan. Pertumbuhan perusahaan (growth) adalah seberapa jauh perusahaan menempatkan diri dalam sistem ekonomi secara keseluruhan atau sistem ekonomi untuk industri yang sama (Machfoedz, 1996). Pada umumnya, perusahaan yang tumbuh dengan cepat memperoleh hasil yang positif. Pertumbuhan cepat juga memaksa sumber daya manusia yang dimiliki untuk secara optimal memberikan kontribusinya (Kadek, 2011 dalam Syardiana, dkk, 2015). Pertumbuhan dinyatakan sebagai total aset dimana total aset masa lalu akan menggambarkan profitabilitas yang akan datang dan pertumbuhan yang akan datang (Soliha dan Taswan, 2003). Perusahaan yang baru berdiri atau perusahaan kecil pada tahap pertumbuhan mengalami kenaikan penjualan yang menuntut adanya penambahan aset, karena pertumbuhan tidak akan terjadi seperti yang diharapkan tanpa kenaikan pada asetnya. Lebih dari itu pertumbuhan pada aset tersebut biasanya didanai dengan penambahan hutang atau modal baru (Sartono, 2010).

Dari beberapa pendapat diatas dapat disimpulkan bahwa Pertumbuhan adalah seberapa jauh perusahaan menempatkan diri dalam sistem ekonomi secara keseluruhan atau sistem ekonomi untuk industri yang sama. Pada umumnya, perusahaan yang tumbuh dengan cepat memperoleh hasil positif dalam artian pemantapan posisi di dunia persaingan usaha, menikmati penjualan yang meningkat secara signifikan dan diiringi oleh adanya peningkatan pangsa pasar. Perusahaan yang tumbuh cepat juga menikmati 
keuntungan dari citra positif yang diperoleh, akan tetapi perusahaan harus ekstra hatihati karena kesuksesan yang diperoleh menyebabkan perusahaan rentan terhadap isu-isu negatif. Pertumbuhan yang cepat memaksa sumber daya manusia yang dimiliki memberikan kontribusi secara optimal (Machfoedz, 1996).

Growth adalah perubahan (penurunan atau peningkatan) total aktiva yang dimiliki oleh perusahaan. Pertumbuhan aset dihitung sebagai persentase perubahan aset pada saat tertentu terhadap tahun sebelumnya (Saidi, 2004). Berdasarkan difinisi di atas dapat dijelaskan Growth merupakan perubahan total aset baik berupa peningkatan maupun penurunan yang dialami oleh perusahaan selama satu periode (satu tahun), yang digambarkan dengan rasio sebagai berikut:

Perubahan Total Aktiva $=\frac{\text { Total Aktiva }- \text { Total Aktiva } t-1}{\text { Total Aktiva } t-1} \times 100 \%$

Pertumbuhan aset menggambarkan pertumbuhan aktiva perusahaan yang akan mempengaruhi profitabilitas perusahaan yang menyakini bahwa persentase perubahan total aktiva merupakan indikator yang lebih baik dalam mengukur growth perusahaan (Oktarina, 2015). Ukuran yang digunakan adalah dengan menghitung proporsi kenaikan atau penurunan aktiva. Pada penelitian ini, pertumbuhan perusahaan diukur dari proporsi perubahan aset, untuk membandingkan kenaikan atau penurunan atas total aset yang dimiliki oleh perusahaan (Fau dan Hidayati, 2014).

Profitabilitas. Profitabilitas merupakan gambaran dari kinerja manajemen dalam mengelola perusahaan. Ukuran profitabilitas perusahaan dapat berbagai macam seperti: laba operasi, laba bersih, tingkat pengembalian invetasi/aktiva, dan tingkat pengembalian ekuitas pemilik. Robert (1997) mengungkapkan bahwa rasio profitabilitas atau rasio rentabilitas menunjukan keberhasilan perusahaan dalam menghasilkan keuntungan.

Return on equity (ROE) merupakan tingkat pengembalian atas ekuitas pemilik perusahaan. Ekuitas pemilik adalah jumlah aktiva bersih perusahaan. Return on equity atau return on net worth mengukur kemampuan perusahaan memperoleh laba yang tersedia bagi pemegang saham perusahaan (Sartono, 2010). Return on equity merupakan rasio yang sangat penting bagi pemilik perusahaan (the common stockholder), karena rasio ini menunjukkan tingkat kembalian yang dihasilkan oleh manajemen dari modal yang disediakan oleh pemilik perusahaan. Dengan kata lain, ROE menunjukkan 
keuntungan yang akan dinikmati oleh pemilik saham. Adanya pertumbuhan ROE menunjukkan prospek perusahaan yang semakin baik karena berarti adanya potensi peningkatan keuntungan yang diperoleh perusahaan. Hal ini ditangkap oleh investor sebagai sinyal positif dari perusahaan sehingga akan meningkatkan kepercayaan investor serta akan mempermudah manajemen perusahaan untuk menarik modal dalam bentuk saham. Apabila terdapat kenaikkan permintaan saham suatu perusahaan, maka secara tidak langsung akan menaikkan harga saham tersebut di pasar modal. Oleh karena itu dalam penelitian ini rasio profitabilitas yang digunakan adalah return on equity yang dapat dirumuskan sebagai berikut (Sartono, 2010):

$$
R O E=\frac{\text { Laba Setelah Pajak }(\text { EAT })}{\text { Modal Sendiri }} \times 100 \%
$$

\section{Paradigma Penelitian dan Perumusan Hipotesis}

Berdasarkan kajian pustaka dan hasil penelitian empiris yang telah dilakukan sebelumnya, maka hipotesis untuk penelitian ini sebagai berikut:

H1 Struktur Modal berpengaruh signifikan terhadap Nilai Perusahaan pada perusahaan pertambangan di Bursa Efek Indonesia.

H2 Pertumbuhan Perusahaan berpengaruh signifikan terhadap Nilai Perusahaan pada perusahaan pertambangan di Bursa Efek Indonesia.

H3 Struktur Modal berpengaruh signifikan terhadap Profitabilitas pada perusahaan pertambangan di Bursa Efek Indonesia.

H4 Pertumbuhan Perusahaan berpengaruh signifikan terhadap Profitabilitas pada perusahaan pertambangan di Bursa Efek Indonesia.

H5 Profitabilitas berpengaruh signifikan terhadap Nilai Perusahaan pada perusahaan pertambangan di Bursa Efek Indonesia.

H6 Profitabilitas mampu memediasi pengaruh Struktur Modal terhadap Nilai Perusahaan pada perusahaan pertambangan di Bursa Efek Indonesia.

H7 Profitabilitas mampu memediasi pengaruh Pertumbuhan Perusahaan terhadap Nilai Perusahaan pada perusahaan pertambangan di Bursa Efek Indonesia. 
H8 Struktur Modal dan Pertumbuhan Perusahaan secara bersama-sama berpengaruh signifikan terhadap Profitabilitas pada perusahaan pertambangan di Bursa Efek Indonesia.

H9 Struktur modal, Pertumbuhan Perusahaan dan Profitabilitas secara bersamasama berpengaruh signifikan terhadap Nilai Perusahaan pada perusahaan pertambangan di Bursa Efek Indonesia.

Hubungan akan hal ini digambarkan dalam paradigma penelitian berikut ini:

Gambar 1 Gambar Paradigma Penelitian

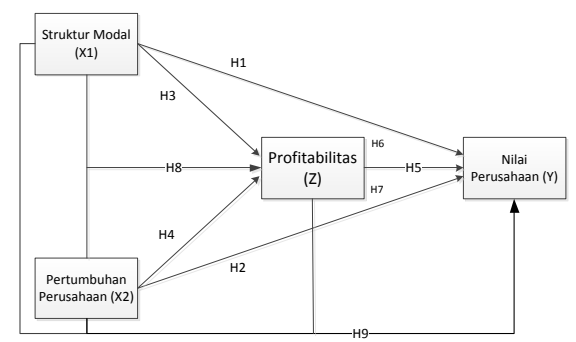

\section{METODE PENELITIAN}

\subsection{Desain Penelitian}

Objek penelitian ini adalah Nilai Perusahaan karena mencerminkan kinerja perusahaan yang dapat mempengaruhi persepsi investor terhadap perusahaan. Nilai perusahaan yang baik akan membuat investor percaya pada kinerja perusahaan dan prospek perusahaan di masa yang akan datang. Penelitian ini menganalisis bagaimana dan seberapa besar Struktur Modal dan Pertumbuhan Perusahaan mempengaruhi Nilai Perusahaan dengan dimediasi oleh Profitabilitas pada perusahaan-perusahaan yang bergerak di sektor pertambangan yang terdaftar di Bursa Efek Indonesia (BEI) periode Laporan Keuangan 2013-2017. Subjek penelitian ini adalah perusahaan-perusahaan yang berada dalam sektor pertambangan yang terdaftar di Bursa Efek Indonesia (BEI). Studi kausalitas yang juga biasa disebut kausal-komparatif berusaha mengamati alasan atau penyebab terjadinya sebuah fenomena yang diteliti. Peneliti berusaha untuk mengidentifikasi faktor utama yang menyebabkan perbedaan tersebut. Penelitian ini menggunakan jenis data panel. Penelitian ini menggunakan data dengan sumber data sekunder. Data yang digunakan dalam penelitian ini adalah data tahunan yang telah diaudit. Data sekunder dalam penelitian ini berupa debt to equity ratio (DER), 
pertumbuhan aset, return on equity (ROE), dan price book value (PBV), dimana datadata tersebut bersumber dari laporan keuangan perusahaan pertambangan yang listing di BEI periode tahun 2013-2017 yang termuat dalam Indonesian Capital Market Directory (ICMD).

\subsection{Populasi dan Sampel Penelitian}

Populasi dari penelitian ini adalah seluruh perusahaan-perusahaan sektor pertambangan yang terdaftar di BEI periode 2013-2017 yang berjumlah 41 emiten. Berdasarkan pertimbangan khusus, tujuan penelitian, dan penjelasan yang telah disebutkan sebelumnya, maka teknik sampel yang digunakan adalah non random/non probability sampling dengan metode purposive sampling. Maka dari itu untuk mencerminkan populasi digunakanlah sampling perusahaan dengan kriteria sebagai berikut:

1. Telah terdaftar (Initial Public Offering, IPO) pada BEI sebelum tahun 2013;

2. Telah masuk ke dalam sektor pertambangan pada BEI sebelum tahun 2013;

3. Tidak delisting dari bursa saham BEI pada periode tahun 2013 sampai dengan 2017; dan

4. Memiliki laporan keuangan lengkap yang telah dari periode tahun 2013 sampai dengan 2017.

Berdasarkan kriteria di atas maka jumlah sampel yang digunakan pada penelitian ini sebanyak 165 data yang diperoleh dari 33 emiten dengan periode selama 2013-2017 (5 tahun).

\subsection{Metode Analisis}

Berdasarkan masalah dan tujuan penelitian, jumlah variabel, jenis hipotesis dan bentuk hubungan antara variabel maka teknik analisis yang digunakan dalam penelitian ini adalah dengan menggunakan Metode Estimasi Path Analysis dengan menggunakan Data Panel Random Effect atau Fixed Effect. Hal yang pertama dilakukan adalah menentukan model/metode estimasi regresi data panel yang tepat dalam penelitian ini, yakni antara common effect, fixed effect atau random effect. 
Kemudian dilanjutkan uji asumsi klasik yang terdiri dari Normalitas, Multikolinearitas, Heteroskedastisitas dan Autokorelasi. Lalu dilanjutkan dengan Uji Signifikansi dengan Uji F, Uji T dan Uji Koefisien Determinasi. Karena penelitian ini menggunakan metode path analyais maka tahapan-tahapan tersebut diterapkan untuk dua model.

Model pertama yaitu Struktur Modal dan Pertumbuhan Perusahaan sebagai variabel independen dan Profitabilitas sebagai varibel dependen. Kemudian yang kedua adalah dengan Struktur Modal dan Pertumbuhan Perusahaan sebagai variabel independen, Profitabilitas sebagai variabel intervening dan Nilai Perusahaan sebagai variabel dependen. Pengukuran dilakukan baik untuk mengetahui pengaruh langsung, pengaruh tidak langsung dan pengaruh total.

\section{HASIL PENELITIAN DAN BAHASAN}

Penelitian ini menggunakan data yang bersumber dari laporan keuangan yang telah diaudit dan histori saham selama periode 2013 - 2017 sektor pertambangan untuk proses analisis data.

\subsection{Hasil Analisis Data}

Metode estimasi analisis jalur dengan menggunakan data panel dapat dilakukan tiga jenis metode estimasi yaitu Common Effect, Fixed Effect atau Random Effect. Kemudian dilanjutkan dengan uji asumsi klasik, uji hipotesis dan interpretasi. Pemilihan metode estimasi, uji asumsi klasik dan uji hipotesis dilakukan untuk dua jalur. Jalur 1 adalah Struktur Modal (X1) dan Pertumbuhan Perusahaan (X2) sebagai variabel independen sedangkan Profitabilitas (Z) sebagai variabel dependen. Jalur 2 adalah Struktur Modal (X1) dan Pertumbuhan Perusahaan (X $\neg 2)$ sebagai variabel independen, Profitabilitas (Z) sebagai variabel intervening dan Nilai Perusahaan (Y) sebagai variabel dependen. Di mana Debt-to-Equty Ratio (DER) merupakan proksi dari Struktur Modal, Perubahan Total Aset sebagai proksi dari Pertumbuhan Perusahaan, Return On Equity (ROE) sebagai proksi dari Profitabilitas dan Price to Book Value (PBV) sebagai proksi dari Nilai Perusahaan

Pemilihan Model Estimasi Regresi. Untuk memilih metode estimasi yang tepat untuk digunakan dalam penelitian ini maka terdapat beberapa langkah pengujian yang harus dilakukan. Pertama adalah melakukan uji Chow, kedua adalah uji Hausman dan 
ketiga adalah Uji Lagrange Multiplier. Ketiga uji tersebut dilakukan untuk jalur 1 dan jalur 2. Dari hasil pemilihan metode estimasi yang telah dilakukan, metode estimasi regresi data panel yang paling tepat untuk Jalur 1 adalah Common Effect sedangkan untuk Jalur 2 adalah Random Effect.

Uji Asumsi Klasik. Berikut adalah hasil uji asumsi klasik pada penelitian ini:

Tabel 2 Hasil Uji Asumsi Klasik

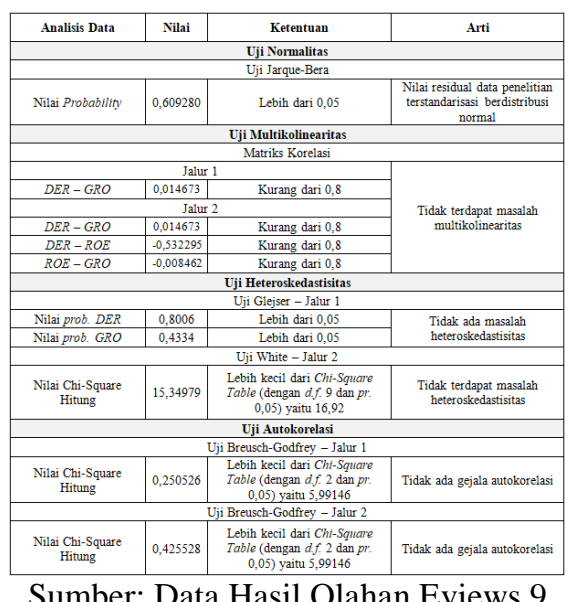

Persamaan Regresi. Berikut adalah hasil estimasi regresi Jalur 1 dan 2 pada data yang diteliti setelah dilakukan uji asumsi klasik:

Tabel 3 Hasil Output Regresi Data Panel Jalur 1

\begin{tabular}{|c|c|c|c|c|}
\hline $\begin{array}{l}\text { Dependent Variable: } \\
\text { Method: Panel Least } \\
\text { Date: } 01 / 06 / 19 \text { Time } \\
\text { Sample: } 20132017 \\
\text { Periods included: } 5 \\
\text { Cross-sections includ } \\
\text { Total panel (balanced }\end{array}$ & $\begin{array}{l}33 \\
\text { servations: } 16\end{array}$ & & & \\
\hline Variable & Coefficient & Std. Error & $\mathrm{t}$-Statistic & Prob. \\
\hline c & 16.60225 & 3.901664 & 4.255172 & 0.0000 \\
\hline DER & -8.557088 & 1.069370 & -8.001988 & 0.0000 \\
\hline GRO & -0.033919 & 3.462513 & -0.009796 & 0.9922 \\
\hline R-squared & 0.283338 & Mean depenc & entvar & 7.943159 \\
\hline Adjusted R-squared & 0.274490 & S.D. depende & ttvar & 55.43665 \\
\hline S.E. of regression & 47.21920 & Akaike info cr & erion & 10.56549 \\
\hline Sum squared resid & 361203.7 & Schwarz crite & & 10.62196 \\
\hline Log likelihood & -868.6531 & Hannan-Quin & criter. & 10.58842 \\
\hline F-statistic & 32.02400 & Durbin-Watsc & & 2.392961 \\
\hline Prob(F-statistic) & 0.000000 & & & \\
\hline
\end{tabular}

Persamaan regresi jalur model 1 dimana DER (X1) dan GRO (X2) sebagai variabel independen yang mempengaruhi ROE (Z) sebagai variabel dependen adalah sebagai berikut:

$$
\mathrm{ROE}=16,60225-8,557088 \mathrm{DER}-0,033919 \mathrm{GRO}+\mathrm{e} 1
$$


Nilai constant sebesar 16,60225 menunjukkan bahwa ROE (Z) akan tetap bernilai 16,60225 satuan meskipun DER (X1) dan GRO (X2) adalah nol. Koefisien Regresi dari DER (X1) adalah sebesar -8,557088 maka dapat diartikan bahwa setiap peningkatan DER (X1) sebesar satu satuan akan mengurangi nilai ROE (Z) sebesar 8,557088 satuan dengan GRO (X2) bernilai tetap, dan sebaliknya. Koefisien Regresi dari GRO (X2) adalah sebesar -0,033919 maka dapat diartikan bahwa setiap peningkatan GRO (X2) sebesar satu satuan akan mengurangi nilai ROE (Z) sebesar 0,033919 satuan dengan DER (X1) bernilai tetap, dan sebaliknya. Sementara itu untuk nilai e1 dapat dicari dengan rumus e1 $=\sqrt{ }(1-0,27449)=0,851769$.

Tabel 4 Hasil Output Regresi Data Panel Jalur 2

\begin{tabular}{|c|c|c|c|c|}
\hline \multicolumn{5}{|c|}{$\begin{array}{l}\text { Dependent Variable: PBV } \\
\text { Method: Panel EGLS (Cross-section random effects) } \\
\text { Date: } 01 / 06 / 19 \text { Time: } 08: 14 \\
\text { Sample: } 20132017 \\
\text { Periods included: } 5 \\
\text { Cross-sections included: } 33 \\
\text { Total panel (balanced) observations: } 165 \\
\text { Swamy and Arora estimator of component variances }\end{array}$} \\
\hline Variable & Coefficient & Std. Error & t-Statistic & Prob. \\
\hline $\mathrm{C}$ & 1.381977 & 0.238545 & 5.793352 & 0.0000 \\
\hline DER & 0.138297 & 0.028430 & 4.864553 & 0.0000 \\
\hline GRO & -0.083588 & 0.069126 & -1.209213 & 0.2284 \\
\hline ROE & -0.000895 & 0.001596 & -0.560658 & 0.5758 \\
\hline \multicolumn{5}{|c|}{ Effects Specification } \\
\hline & & & S.D. & Rho \\
\hline Cross-section random & & & 1.295270 & 0.6915 \\
\hline Idiosyncratic random & & & 0.865158 & 0.3085 \\
\hline \multicolumn{5}{|c|}{ Weighted Statistics } \\
\hline R-squared & 0.188984 & \multirow{5}{*}{\multicolumn{2}{|c|}{$\begin{array}{l}\text { Mean dependent var } \\
\text { S.D. dependent var } \\
\text { Sum squared resid } \\
\text { Durbin-Watson stat }\end{array}$}} & 0.428334 \\
\hline Adjusted R-squared & 0.173872 & & & 0.947405 \\
\hline S.E. of regression & 0.861112 & & & 119.3836 \\
\hline F-statistic & 12.50551 & & & 1.384140 \\
\hline Prob(F-statistic) & 0.000000 & & & \\
\hline \multicolumn{5}{|c|}{ Unweighted Statistics } \\
\hline R-squared & 0.104395 & \multirow{2}{*}{\multicolumn{2}{|c|}{$\begin{array}{l}\text { Mean dependent var } \\
\text { Durbin-Watson stat }\end{array}$}} & 1.496553 \\
\hline Sum squared resid & 374.9094 & & & 0.440756 \\
\hline
\end{tabular}

Persamaan regresi jalur model 2 dimana DER (X1) dan GRO (X2) sebagai variabel independen yang mempengaruhi PBV (Y) sebagai variabel dependen melalui ROE (Z) sebagai variabel intervening adalah sebagai berikut:

$$
\mathrm{PBV}=1,381977+0,138297 \mathrm{DER}-0,083588 \mathrm{GRO}-0,000895 \mathrm{ROE}+\mathrm{e} 1+\mathrm{e} 2
$$

Nilai constant sebesar 1,381977 menunjukkan bahwa PBV (Y) akan tetap bernilai 1,381977 satuan meskipun DER (X1), GRO (X2) dan ROE (Z) adalah nol. Koefisien Regresi dari DER (X1) adalah sebesar 0,138297 maka dapat diartikan bahwa setiap peningkatan DER (X1) sebesar satu satuan akan menambah nilai PBV (Y) 
sebesar 0,138297 satuan dengan variabel lain bernilai tetap, dan sebaliknya. Koefisien Regresi dari GRO (X2) adalah sebesar -0,083588 maka dapat diartikan bahwa setiap peningkatan GRO (X2) sebesar satu satuan akan mengurangi nilai PBV (Y) sebesar 0,083588 satuan dengan variabel lain bernilai tetap, dan sebaliknya. Koefisien Regresi dari ROE (Z) adalah sebesar -0,000895 maka dapat diartikan bahwa setiap peningkatan ROE (Z) sebesar satu satuan akan mengurangi nilai PBV (Y) sebesar 0,000895 satuan dengan variabel lain bernilai tetap, dan sebaliknya. Sementara itu untuk nilai e2 dapat dicari dengan rumus e $2=\sqrt{ }(1-0,173872)=0,908916$.

Hasil Uji Hipotesis. Berikut adalah hasil uji hipotesis dalam penelitian ini, yang terdiri dari uji t, uji Analisis Jalur, uji F dan Koefisien Determinasi.

Tabel 4 Hasil Uji Hipotesis

\begin{tabular}{|c|c|c|c|c|c|}
\hline \multicolumn{2}{|c|}{ Uji t (Uji Signifikansi Individual) } & t-Stantistic & Nilait Tabel & $\begin{array}{l}\text { Nilai } \\
\text { prob. }\end{array}$ & Hasil \\
\hline \multicolumn{2}{|c|}{$\begin{array}{l}D E R \text { berpengaruh signifikan terhadap } P B V \\
\text { pada perusahasan pertambangan di Bursa Efek } \\
\text { Indonesia }\end{array}$} & 4,864553 & \multirow{5}{*}{1,97481} & 0,0000 & Diterima \\
\hline \multicolumn{2}{|c|}{$\begin{array}{l}\text { GRO berpengaruh signifikan terhadap PBV } \\
\text { pada perusahaan pertambangan di Bursa Efek } \\
\text { Indonesia }\end{array}$} & $-1,209213$ & & 0,2284 & Ditolak \\
\hline \multicolumn{2}{|c|}{$\begin{array}{l}D E R \text { berpengaruh signifikan terhadap ROE } \\
\text { pada perusahasan pertambangan di Bursa Efek } \\
\text { Indonesia }\end{array}$} & $-8,001988$ & & 0,0000 & Diterima \\
\hline \multicolumn{2}{|c|}{$\begin{array}{l}\text { GRO berpengaruh signifikan terhadap } R O E \\
\text { pada perusahann pertambangan di Bursa Efek } \\
\text { Indonesia }\end{array}$} & $-0,009796$ & & 0,9922 & Ditolak \\
\hline \multicolumn{2}{|c|}{$\begin{array}{l}R O E \text { berpengaruh signifikan terhadap } P B V \\
\text { pada perusahan pertambangan di Bursa Efek } \\
\text { Indonesia }\end{array}$} & $-0,560658$ & & 0,5758 & Ditolak \\
\hline \multicolumn{2}{|c|}{ Analisis Jalur (Path Analysis) } & $\begin{array}{l}\text { Pengaruh } \\
\text { Langsung }\end{array}$ & \multicolumn{2}{|c|}{\begin{tabular}{|c|}
$\begin{array}{c}\text { Pengaruh Tidak } \\
\text { Langsung }\end{array}$ \\
\end{tabular}} & Hasil \\
\hline \multirow{2}{*}{\multicolumn{2}{|c|}{$\begin{array}{l}R O E \text { mampu memediasi pengaruh } D E R \\
\text { terhadap } P B V \text { pada perusahasan pertambangan } \\
\text { di Bursa Efek Indonesia } \\
R O E \text { mampu memediasi pengaruh GRO } \\
\text { terhadap } P B V \text { pada perusahas pertambangan } \\
\text { di Bursa Efek Indonesia } \\
\end{array}$}} & 0,138297 & \multicolumn{2}{|c|}{0,007658} & \begin{tabular}{|c|c|} 
Tidalk \\
Memadiasi \\
\end{tabular} \\
\hline & & $-0,083588$ & 0,00 & 0030 & \begin{tabular}{|c} 
Mampu \\
Memadiasi
\end{tabular} \\
\hline \multicolumn{2}{|c|}{ Uji F (Uji Signifikansi Simultan) } & F-Statistic & \multicolumn{2}{|c|}{ Nilai F Tabel } & Hasil \\
\hline \multirow{2}{*}{\multicolumn{2}{|c|}{$\begin{array}{l}D E R \text { dan GRO secara bersama-5ama } \\
\text { berpengaruh signifikan terhadap } R O E \text { pada } \\
\text { perusahagn pertambangan di Bursa Efek } \\
\text { Indonesia } \\
D E R, G R O, \text { dan } R O E \text { secara bersama-sama } \\
\text { berpengaruh signifikan terhadap } P B V \text { pada } \\
\text { perusahaan pertambangan di Bursa Efek } \\
\text { Indonesia }\end{array}$}} & 32,02400 & \multicolumn{2}{|c|}{3,05} & Diterima \\
\hline & & 12,50551 & \multicolumn{2}{|c|}{2,66} & Diterima \\
\hline Uji Koefisien Determinasi & $\begin{array}{l}\text { Adj. } R \text { - } \\
\text { Squared }\end{array}$ & \multicolumn{4}{|c|}{ Hasil } \\
\hline $\begin{array}{l}\text { Kemampuan model dalam } \\
\text { menerangkanvariasi variabel } \\
\text { dependen pada Jalur } 1\end{array}$ & 0,274490 & \multicolumn{4}{|c|}{$\begin{array}{l}\text { Kemampuan dari variabel } D E R\left(\mathrm{X}_{1}\right) \text { dan } G R O\left(\mathrm{X}_{2}\right) \\
\text { dalam menjelaskan variasi dari variabel } R O E(\mathrm{Z}) \\
\text { adalah sebesar } 27,449 \% \text {, sedangkan sisanya } 72,551 \% \\
\text { dijelaskan oleh variabel independen lainnya yang } \\
\text { tidak dimasukkan ke dalam model penelitian ini }\end{array}$} \\
\hline $\begin{array}{l}\text { Kemampuan model dalam } \\
\text { menerangkanvariasi variabel } \\
\text { dependen pada Jalur } 1\end{array}$ & 0,173872 & \multicolumn{4}{|c|}{$\begin{array}{l}\text { Kemampuan dari variabel DER (X1), GRO (X2), dan } \\
R O E(\mathrm{Z}) \text { dalam menjelaskan variasi dari variabel } \\
P B V(\mathrm{Y}) \text { adalah sebesar } 17,387 \% \text {, sedangkan isany } \\
82,613 \% \text { dijelaskan oleh variabel independen lainny } \\
\text { yang tidak dimasulkan ke dalam model penelitian in }\end{array}$} \\
\hline
\end{tabular}

Sumber: Data Hasil Olahan Eviews 9

\section{INTERPRETASI DATA}

\subsection{Pengaruh Struktur Modal (X1) terhadap Nilai Perusahaan (Y)}

Berdasarkan analisis data di atas, diperoleh hasil bahwa Struktur Modal (X1) berpengaruh signifikan terhadap Nilai Perusahaan (Y) pada perusahaan-perusahaan yang berada di sektor pertambangan yang terdaftar di Bursa Efek Indonesia periode 
2013-2017. Dengan pengaruh positif sebesar 0,138297 sehingga dapat diartikan bahwa setiap peningkatan Struktur Modal (X1) sebesar satu satuan akan meningkatkan nilai Nilai Perusahaan (Y) sebesar 0,138297 satuan.

Semakin besar hutang maka semakin besar nilai perusahaan, selama tidak melebihi titik optimal. Penggunaan hutang dapat meningkatkan nilai perusahaan sejauh penggunaan hutang memberikan manfaat dan tidak berada di atas nilai optimal. Dengan meningkatnya Debt-to-Equity Ratio yang artinya proporsi hutang juga meningkat, maka dalam kondisi tersebut akan membuat nilai dari Weighted Average Cost of Capital (WACC) turun. Penurunan nilai WACC akan membuat peningkatan harga pasar saham sekaligus dengan tingkat pengembaliannya. Peningkatan harga pasar saham dan tingkat pengembaliannya akan membuat Price to Book Value (PBV) meningkat, sehingga nilai perusahaan pun meningkat.

Hasil penelitian ini mendukung penelitian yang telah dilakukan oleh Febriana, Djumahir dan Djawahir (2016), Limbong dan Chabachib (2016) dan Yuanita, dkk (2016) dan Sari (2017) yang menyatakan bahwa struktur modal berpengaruh positif dan signifikan terhadap Nilai Perusahaan. Hasil penelitian ini tidak mendukung penelitian yang telah dilakukan oleh Chandra (2007), Herawati (2013), dan Suastini, Purbawangsa dan Rahyuda (2016) yang menyatakan bahwa struktur modal tidak berpengaruh signifikan terhadap nilai perusahaan dengan arah pengaruh positif..

\subsection{Pengaruh Pertumbuhan Perusahaan (X2) terhadap Nilai Perusahaan (Y)}

Berdasarkan analisis data di atas, diperoleh hasil bahwa Pertumbuhan Perusahaan (X2) tidak berpengaruh signifikan terhadap Nilai Perusahaan (Y) pada perusahaan-perusahaan yang berada di sektor pertambangan yang terdaftar di Bursa Efek Indonesia periode 2013-2017. Dengan pengaruh negatif sebesar -0,083588 sehingga dapat diartikan bahwa setiap peningkatan Pertumbuhan Perusahaan (X2) sebesar satu satuan akan menurunkan nilai dari Nilai Perusahaan (Y) sebesar 0,083588 satuan namun tidak secara signifikan.

Perusahaan dengan pertumbuhan yang tinggi belum tentu memiliki nilai perusahaan yang tinggi ataupun sebaliknya, perusahaan dengan pertumbuhan yang rendah belum tentu memiliki nilai perusahaan yang rendah. Hal tersebut dapat terjadi ketika turunnya Pertumbuhan Perusahaan yang disebabkan oleh meningkatnya 
pengeluaran operasional produksi perusahaan akan dianggap investor sebagai sinyal positif untuk proyeksi keuntungan di masa mendatang. Hal tersebut dapat diartikan juga bahwa perusahaan pertambangan masih mampu memberikan keuntungan bagi investor secara jangka panjang. Meningkatnya harapan dari investor tersebut membuat banyak investor saling bersaing dalam membeli saham. Kemudian meningkatnya harga saham akibat meningkatnya minat investor tersebut akan membuat Price to Book Value perusahaan pertambangan akan meningkat

Hasil penelitian ini mendukung penelitian yang telah dilakukan oleh Limbong dan Chabachib (2016) dan Widayanti dan Sudiartha (2018) yang menyebutkan bahwa Pertumbuhan Perusahaan berpengaruh dengan arah negatif terhadap Nilai Perusahaan namun tidak sgnifikan. Hasil penelitian ini tidak mendukung penelitian yang telah dilakukan oleh Yuanita, dkk (2016) dan Dhani dan Utama (2017). Penelitian-penelitian tersebut menyebutkan bahwa Pertumbuhan Perusahaan berpengaruh positif namun tidak signifikan terhadap Nilai Perusahaan.

\subsection{Pengaruh Struktur Modal (X1) terhadap Profitabilitas (Z)}

Berdasarkan analisis data di atas, diperoleh hasil bahwa Struktur Modal (X1) berpengaruh signifikan terhadap Profitabilitas ( $Z$ ) pada perusahaan-perusahaan yang berada di sektor pertambangan yang terdaftar di Bursa Efek Indonesia periode 20132017. Dengan pengaruh negatif sebesar $-8,557088$ sehingga dapat diartikan bahwa setiap peningkatan Struktur Modal (X1) sebesar satu satuan akan mengurangi nilai Profitabilitas (Z) sebesar 8,557088 satuan.

Semakin besar hutang maka tingkat profitabilitas akan semakin kecil. Hal tersebut dapat terjadi disebabkan sebagai dampak dari meningkatnya proporsi hutang perusahaan yang akan membuat meningkatnya kewajiban pokok hutang dan bunga hutang yang harus dilunasi. Beban bunga hutang yang meningkat akan membuat tingkat profitabilitas perusahaan menjadi berkurang dan profitabilitas yang menurun dipengaruhi juga oleh turunnya nilai penjualan karena harga komoditas yang anjlok tahun 2015

Hasil penelitian ini mendukung penelitian yang telah dilakukan oleh Rifai, Arifati dan Maria (2012), Yuliana (2014) dan Oktarina (2015) yang menyatakan bahwa Struktur Modal berpengaruh signifikan terhadap Profitabilitas dengan arah pengaruh 
negatif. Hasil penelitian ini tidak mendukung penelitian yang telah dilakukan oleh Limbong dan Chabachib (2016), Yuanita, dkk (2016) dan Pradnyani, Purbawangsa dan Artini (2017) yang menyebutkan bahwa Struktur Modal memiliki pengaruh yang signifikan terhadap Profitabilitas dengan arah pengaruh positif..

\subsection{Pengaruh Pertumbuhan Perusahaan (X2) terhadap Profitabilitas (Z)}

Berdasarkan analisis data di atas, diperoleh hasil bahwa Pertumbuhan Perusahaan (X2) tidak berpengaruh signifikan terhadap Profitabilitas (Z) pada perusahaan-perusahaan yang berada di sektor pertambangan yang terdaftar di Bursa Efek Indonesia periode 2013-2017. Dengan pengaruh negatif sebesar -0,033919 sehingga dapat diartikan bahwa setiap peningkatan Pertumbuhan Perusahaan (X2) sebesar satu satuan akan mengurangi nilai Profitabilitas (Z) sebesar 0,033919 satuan.

Perusahaan yang memiliki tingkat pertumbuhan yang tinggi belum tentu memiliki tingkat profitabilitas yang tinggi ataupun sebaliknya, perusahaan dengan nilai pertumbuhan yang rendah belum tentu memiliki profitabilitas yang rendah. Hal itu terjadi disebabkan karena turunnya nilai aset perusahaan yang digunakan untuk membayar hutang. Kemudian membuat beban bunga hutang juga akan berkurang. Berkurangnya beban bunga akan berkontribusi dalam meningkatnya profitabilitas perusahaan Di sisi lain, harga-harga komoditas sektor pertambangan sudah mulai membaik, yang mana membuat nilai penjualan meningkat sehingga profitabilitas perusahaan pertambangan juga semakin membaik

Hasil penelitian ini mendukung penelitian yang telah dilakukan oleh Rifai, Arifati dan Maria (2012) dan Oktarina (2015) yang menyatakan bahwa Pertumbuhan Perusahaan berpengaruh tidak secara signifikan terhadap Profitabilitas dengan arah pengaruh negatif. Hasil penelitian ini tidak mendukung penelitian yang telah dilakukan oleh Pradnyani, Purbawangsa dan Artini (2017) yang menyebutkan bahwa Pertumbuhan Perusahaan berpengaruh secara signifikan terhadap Profitabilitas dengan arah pengaruh positif dan Tandi, Tommy dan Untu (2018) yang menyebutkan bahwa Pertumbuhan Perusahaan memiliki pengaruh yang tidak signifikan terhadap Nilai Perusahaan dengan arah pengaruh positif. 


\subsection{Pengaruh Profitabilitas (Z) terhadap Nilai Perusahaan (Y)}

Berdasarkan analisis data di atas, diperoleh hasil bahwa Profitabilitas (Z) tidak berpengaruh signifikan terhadap Nilai Perusahaan (Y) pada perusahaan-perusahaan yang berada di sektor pertambangan yang terdaftar di Bursa Efek Indonesia periode 2013-2017. Dengan pengaruh negatif sebesar -0,000895 sehingga dapat diartikan bahwa setiap peningkatan Profitabilitas $(Z)$ sebesar satu satuan akan mengurangi nilai Nilai Perusahaan (Z) sebesar 0,000895 satuan.

Perusahaan yang memiliki tingkat profitabilitas tinggi belum tentu memiliki nilai perusahaan yang tinggi pula ataupun sebaliknya, perusahaan yang memilki profitabilitas yang rendah belum tentu memiliki nilai perusahaan yang rendah. Hal itu dapat terjadi karena berkurangnya tingkat Return On Equity disebabkan oleh meningkatnya pengeluaran-pengeluaran operasional perusahaan. Meningkatnya operating expenditures merupakan sinyal positif bagi investor karena dinilai merupakan persiapan dari proyek-proyek yang mampu menghasilkan keuntungan di masa mendatang. Meningkatnya harapan investor akan terceminkan dari meningkatnya pembelian harga saham, yang kemudian akan meningkatkan harga saham itu sendiri, sehingga Price to Book Value akan meningkat dan banyak faktor yang mempengaruhi nilai perusahaan selain profitabilitas yaitu, Ukuran Perusahaan, Kebijakan Dividen dan Kepemilikan Saham Manajerial.

Hasil penelitian ini mendukung penelitian yang telah dilakukan oleh Listari (2018) yang menyebutkan bahwa Profitabilitas tidak memiliki pengaruh yang signifikan terhadap Nilai Perusahaan dengan arah pengaruh negatif. Hasil penelitian juga sedikit mendukung penelitian yang dilakukan oleh Herawati (2013) yang menyebutkan bahwa Profitabilitas memiliki pengaruh negatif dan signifikan terhadap Nilai Perusahaan. Perbedaannya berada di tingkat signifikansi. Hasil penelitian ini tidak mendukung penelitian yang telah dilakukan oleh Febriana, Djumahir dan Djawahir (2016) dan Dhani dan Utama (2017) yang menyebutkan bahwa Profitabilitas berpengaruh signifikan positif terhadap Nilai Perusahaan.

Kemampuan Profitabilitas (Z) dalam Memediasi Pengaruh Struktur Modal (X1) dan Pertumbuhan Perusahaan (X2) terhadap Nilai Perusahaan (Y) 
Profitabilitas tidak mampu memediasi pengaruh Struktur Modal terhadap Nilai Perusahaan pada perusahaan-perusahaan pertambangan yang terdaftar di Bursa Efek Indonesia selama periode 2013-2017. Hal ini disebabkan oleh perbedaan arah pengaruh. Dalam penelitian ini Struktur Modal berpengaruh signifikan terhadap Nilai Perusahaan dengan arah pengaruh positif, sedangkan Profitabilitas tidak berpengaruh secara signifikan terhadap Nilai Perusahaan dengan arah pengaruh negatif.

Profitabilitas mampu memediasi pengaruh Pertumbuhan Perusahaan terhadap Nilai Perusahaan pada perusahaan-perusahaan pertambangan yang terdaftar di Bursa Efek Indonesia selama periode 2013-2017. Karena berdasarkan hasil perhitungan yang telah dilakukan, diketahui bahwa pengaruh tidak langsung lebih besar dibandingkan dengan pengaruh langsung, dimana pengaruh tidak langsung senilai 0,000030 lebih besar daripada pengaruh tidak langsung senilai $-0,083588$

\section{SIMPULAN DAN SARAN}

\subsection{Simpulan}

Berdasarkan penelitian yang telah dilakukan dan dijelaskan pada bab-bab sebelumnya, maka diperoleh kesimpulan sebagai berikut:

1. Struktur Modal berpengaruh signifikan terhadap Nilai Perusahaan pada perusahaan-perusahaan sektor pertambangan yang terdaftar di Bursa Efek Indonesia selama periode 2013-2017, dengan arah pengaruh positif (searah).

2. Pertumbuhan Perusahaan tidak berpengaruh signifikan terhadap Nilai Perusahaan pada perusahaan-perusahaan sektor pertambangan yang terdaftar di Bursa Efek Indonesia selama periode 2013-2017.

3. Struktur Modal berpengaruh signifikan terhadap Profitabilitas pada perusahaanperusahaan sektor pertambangan yang terdaftar di Bursa Efek Indonesia selama periode 2013-2017 dengan arah pengaruh negatif (berlawanan arah).

4. Pertumbuhan Perusahaan tidak berpengaruh signifikan terhadap Profitabilitas pada perusahaan-perusahaan sektor pertambangan yang terdaftar di Bursa Efek Indonesia selama periode 2013-2017.

5. Profitabilitas tidak berpengaruh signifikan terhadap Nilai Perusahaan pada perusahaan-perusahaan sektor pertambangan yang terdaftar di Bursa Efek Indonesia selama periode 2013-2017. 
6. Profitabilitas tidak mampu memediasi pengaruh Struktur Modal terhadap Nilai Perusahaan pada perusahaan-perusahaan pertambangan yang terdaftar di Bursa Efek Indonesia selama periode 2013-2017.

7. Profitabilitas mampu memediasi pengaruh Pertumbuhan Perusahaan terhadap Nilai Perusahaan pada perusahaan-perusahaan pertambangan yang terdaftar di Bursa Efek Indonesia selama periode 2013-2017.

\subsection{Saran}

Adapun saran yang dapat diberikan guna perbaikan penelitian ini di kemudian hari terbagi menjadi saran operasional dan saran pengembangan ilmu. Saran operasional yang dapat peneliti berikan adalah:

1. Investor harus memperhatikan DER, ROE dan PBV perusahaan-perusahaan pertambangan. Karena ketiga ukuran tersebut merupakan hal penting yang menjadi indikator baik atau buruknya kinerja suatu perusahaan dan prospek di masa yang mendatang;

2. Karena pengaruhnya yang signifikan baik terhadap Profitabilitas atau Nilai Perusahaan, peneliti menyarankan kepada manajemen perusahaan dan investor memperhatikan Struktur Modal dari perusahaan-perusahaan pertambangan sebagai dasar dalam menentukan kebijakan ataupun investasi;

3. Peneliti menyarankan kepada manajemen untuk

a. Menemukan struktur modal yang ideal agar nilai perusahaan dapat menjadi semakin optimal, kemudian hal tersebut mampu menarik perhatian investor untuk berinvestasi sehingga dana modal yang tersedia dapat terus betambah dan perusahaan dapat terus berkembang;

b. Terus melakukan disiplin dan ketat dalam penggunaan modal dan pengeluaran-pengeluaran operasional agar kinerja perusahaan dapat terus terjaga meskipun harga-harga komoditas secara global mengalami penurunan;

c. Selalu menjaga dan meningkatkan performa bisnis mereka dan kinerja keuangan mereka, kemudian melaporkannya sesuai dengan prinsip dan standar yang berlaku di laporan keuangan setiap periode. Jika perusahaan memiliki kinerja yang baik dan dilaporkan pada laporan keuangan secara 
rutin setiap periode dengan benar, maka hal tersebut dapat menarik minat investor untuk berinvestasi. Sehingga perusahaan bisa memperoleh dana tambahan yang dapat digunakan untuk mengembangkan bisnis serta meningkatkan profit dan kekayaan.

Saran pengembangan ilmu yang dapat peneliti berikan kepada penelitia selanjutnya adalah:

1. Menambahkan Pertumbuhan Penjualan dan Earning Per Share sebagai proksi dari variabel Pertumbuhan Perusahaan.

2. Menambahkan Return On Assets dan Net Profit Margin sebagai proksi dari variabel Profitabilitas.

3. Menggunakan metode Strucutral Equation Modeling yang dinilai lebih baik dibandingkan Path Analysis, menambah proksi (setidaknya tiga) untuk setiap variabel independen dan menambah jumlah periode penelitian agar hasil penelitian semakin baik dan tidak bias.

4. Jumlah periode penelitian yang ditambah diharapkan dapat membuat penelitian yang semakin baik dalam konteks Best Linear Unbiased Minimum (BLUE) sehingga hasil interpretasi dari penelitian dapat semakin dikembangkan. Jumlah sampel yang peneliti sarankan adalah sekitar 300 sampel data.

\section{DAFTAR PUSTAKA}

[1] Andrian, Jun. 2012. Pengaruh Struktur Modal, Pertumbuhan Perusahaan, Capital Expenditure dan Insentif Manajer terhadap Nilai Perusahaan dengan Profitabilitas Sebagai Variabel Intervening. Jurnal Bisnis Strategi, Vol. 21 No. 2 Desember 2012.

[2] Ayuningrum, Niken. 2017. Pengaruh Struktur Modal, Pertumbuhan Perusahaan terhadap Nilai Perusahaan dengan Profitabilitas Sebagai Variabel Intervening pada Perusahaan Manufaktur yang Terdaftar di Bursa Efek Indonesia. Jurnal Riset Terapan Akuntansi, Vol. 1 No. 1 Januari 2017.

[3] Basuki, A. Tri \& Prawoto, N. 2016. Analisis Regresi dalam Penelitian Ekonomi \& Bisnis Dilengkapi Aplikasi SPSS \& Eviews. Jakarta: Rajagrafindo Persada.

[4] Brigham, E.F., dan J. Houston. 2001. Manajemen Keuangan. Penerjemah Hermawan Wibowo. Edisi Kedelapan. Edisi Indonesia. Buku II. Jakarta: Erlangga. 
[5] Brigham, E.F., dan J. Houston. 2006. Dasar-Dasar Manajemen Keuangan. Penerjemah Ali Akbar Yulianto. Edisi Kesepuluh. Edisi Indonesia. Buku II. Jakarta: Salemba Empat.

[6] Chandra, Teddy. 2007. Pengaruh Struktur Modal terhadap Produktivitas Aktiva, Kinerja Keuangan dan Nilai Perusahaan. Arthavidya Jurnal Ekonomi, Tahun 8, Nomor 2, Hal. 201. Juni 2007.

[7] Danise, Dickins and Robert, Houmes. 2009. Revisiting The Relationship Between Insider Ownership And Perfomance, Journal of Business and Economic Studies. Vol. 15, No. 2. East Carolina University-Jaksonville University.

[8] Dhani, Isabella Permata dan A.A Gde Satia Utama. 2017. Pengaruh Pertumbuhan Perusahaan, Struktur Modal, dan Profitabilitas terhadap Nilai Perusahaan. Jurnal Riset Akuntansi dan Bisnis Airlangga Vol. 2 No. 1.

[9] Fahmi, I. 2014. Manajemen Keuangan Perusahaan dan Pasar Modal. Jakarta: Mitra Wacana Media.

[10] Fahmi, I. 2015. Analisis Laporan Keuangan. Bandung: Alfabeta.

[11] Fau, Nia Rositawati dan Lina Nur Hidayati. 2014. Pengaruh Struktur Modal, Pertumbuhan Perusahaan, Ukuran Perusahaan dan Profitabilitas terhadap Nilai Perusahaan pada Perusahaan Manufaktur yang Terdaftar di Bursa Efek Indonesia. Jurnal Manajemen Bisnis Indonesia Vol. 4 Edisi IV.

[12] Febriana, E., Djumahir dan Achmad Helmy Djawahir. 2016. Pengaruh Struktur Modal, Kebijakan Dividen, Ukuran Perusahaan, Kepemilikan Saham Manajerial dan Profitabilitas Terhadap Nilai Perusahaan (Studi Pada Perusahaan Manufaktur yang Terdaftar di BEI Pada 2011-2013). Jurnal Ekonomi Bisnis Tahun 21, Nomor 2, Oktober 2016.

[13] Gujarati, Damodar N. dan Porter, Dawin C. 2013. Dasar-dasar Ekonometrika. Buku 1. Edisi ke 5. Terjemahan Eugenia Mardanugraha, Sita Wardhani, dan Carlos Mangunsong. Jakarta: Salemba Empat.

[14] Hadi, Sutrisno. 2015. Metodologi Riset. Yogyakarta: Pustaka Pelajar.

[15] Halim, A. 2015. Manajemen Keuangan Bisnis Konsep dan Aplikasinya. Jakarta: Mitra Wacana Media. 
[16] Helfert, E.A. 1997. Teknik Analsis Keuangan: Petunjuk Praktis untuk Mengelola dan Mengukur Kinerja Perusahaan. Penerjemah Hermawan Wibowo. Edisi Kedelapan. Jakarta: Erlangga.

[17] Herawati, Titin. 2013. Pengaruh Kebijakan Dividen, Kebijakan Hutang dan Profitabilitas terhadap Nilai Perusahaan. Jurnal Manajemen Universitas Negeri Padang Vol 2, No. 02.

[18] Hermuningsih, Sri. 2013. Pengaruh Profitabilitas, Growth Opportunity, Struktur Modal terhadap Nilai Perusahaan pada Perusahaan Publik di Indonesia. Buletin Ekonomi Moneter dan Perbankan, Oktober 2013.

[19] Hery. 2016. Analisis Laporan Keuangan Integrated and Comprehensive Edition, Jakarta: Grasindo.

[20] Hidayati, Eva Eko. 2010. Analisis Pengaruh DER, DPR, ROE dan Size terhadap PBV Perusahaan Manufaktur yang Listing di BEI Periode 2005-2007. Jurnal Bisnis Strategi, Vol. 19, No. 2.

[21] Husnan, 1998, Manajemen Keuangan-Teori dan Penerapan (keputusan jangka panjang), Buku 1, Edisi 4. Yogyakarta: BPFE.

[22] Husnan, S., 2000. Manajemen Keuangan-Teori dan Penerapan (Keputusan Jangka Panjang. Yogyakarta: BPFE.

[23] Jones, M. A, Mothersbaugh, D. L., Beatty, S.E. 2000. Switching barriers and repurchase intentions in services. Journal of Retailing, page 259-274.

[24] Kallapur, S. \& Trombley, M. A. 1999. The Association Between Investment Opportunity Set Proxies and Relized Growth. Journal of Business Finance \& Accounting, Vol. 26 (3) \& (4), 505-519.

[25] Keown. 2004. Manajemen Keuangan : Prinsip-Prinsip dan Aplikasi. Edisi 9. Indeks. Jakarta.

[26] Kuncoro, M. 2013. Metode Riset untuk Bisnis dan Ekonomi Edisi 4. Jakarta: Erlangga.

[27] Limbong, Dita Tessa Sampriani dan Mochamad Chabachib. 2016. Analisis Pengaruh Struktur Modal, Pertumbuhan Penjualan, dan Ukuran Perusahaan terhadap Nilai Perusahaan dengan Profitabilitas sebagai Variabel Intervening (Studi Kasus 
pada Perusahaan Real Estate dan Properti yang Terdaftar di BEI Tahun 2010-2014. Diponegoro Journal of Management, Volume 5, Nomor 4, Halaman 1-14.

[28] Listari, Sinta. 2018. Analisis Faktor-faktor yang Mempengaruhi Nilai Perusahaan pada Perusahaan-perusahaan yang Terdaftar dalam Indekx LQ45 di Bursa Efek Indonesia. Jurnal Ilmiah Manajemen Kesatuan, Vol. 6, No. 1, Hal. 053-062.

[29] Machfoedz, Mas'ud. 1996. Akuntansi Manajemen, Buku 1. Yogyakarta: STIE Widya Wiwaha.

[30] Oktarina, Famela. 2015. Pengaruh Growth Opportunity dan Tax Shield terhadap Struktur Modal dan Kinerja Keuangan Perusahaan (Studi pada Perusahaan Manufaktur Sektor Industri Barang Konsumsi yang Terdaftar di BEI pada Periode 2009-2012). JOM FEKON VOL. 2 No. 1. Februari 2015.

[31] Pongrangga, Dzulkirom, dan Saifi. 2015. Pengaruh Current Ratio, Total Asset Turnover, dan Debt to Equity Ratio terhadap Return On Equity (Studi pada Perusahaan Sub Sektor Property dan Real Estate yang terdaftar di BEI periode 20112014). Jurnal Administrasi Bisnis (JAB),. Vol.25 No. 2, Agustus 2015.

[32] Pradnyani, I Gusti Agung Arista, I.B. Anom Purbawangsa dan Luh Gede Sri Artini. 2017. Peran Profitabilitas dalam Memediasi Pengaruh Pertumbuhan Perusahaan dan Struktur Modal terhadap Corportate Social Responsibility. E-Jurnal Ekonomi dan Bisnis Universitas Udayana 6.5 (2017): 1967-1994.

[33] Pratomo, Aditya Joko. 2017. Pengaruh Debt to Equity Ratio (DER) dan Current Ratio (CR) terhadap Return On Equity (ROE). Studi Empiris pada Perusahaan Sub Sektor Kabel yang Terdaftar di Bursa Efek Indonesia pada Tahun 2013-2016. eJournal Administrasi Bisnis. 5 (4): 942-956, 2017.

[34] Rifai, Moh., Rina Arifati, dan Maria. 2012. Pengaruh Ukuran Perusahaaan, Struktur Modal dan Pertumbuhan Perusahaan terhadap Profitabilitas Studi Pada Perusahaan Manufaktur di BEI Tahun 2010-2012. Jurnal Universitas Pandanaran. Vol. 1 No. 1 Februari 2015.

[35] Robert Ang. 1997. Buku Pintar Pasar Modal Indonesia. Jakarta: Mediasoft Indonesia.

[36] Rosadi, D. 2012. Ekonometrika \& Analisis Runtun Waktu Terapan dengan Eviews. Yogyakarta: Penerbit ANDI. 
[37] Ross, Stephen. A., Westerfield, R.W., dan Jaffe, Jeffrey., 2010. Corporate Finance, Ninth Edition. New York: McGraw-Hill.

[38] Safieddine, Assem dan Sheridan Titman. 1997. Debt and Corporate Performance: Evidence From Unsuccesful Takeovers. NBER Working Paper No. 6068, June 1997 JEL Nos. G32, G33, G34 Corporate Finance.

[39] Safrida, Eli. 2009. Pengaruh Struktur Modal, Pertumbuhan Perusahaan, Profitabilitas dan Ukuran Perusahaan terhadap Nilai Perusahaan (Studi pada Perusahaan Manufaktur di Indonesia). Jurnal Akuntansi Riset, Prodi Akuntansi UPI. [40] Saidi, 2004, Faktor-Faktor yang Mempengaruhi Struktur Modal pada Perusahaan Manufaktur Go Public di BEJ Tahun 1997-2002, Jurnal Bisnis dan Ekonomi, Vo.XI (1).

[41] Salim, Jihan. 2015. Pengaruh Leverage (DAR, DER, dan TIER) terhadap ROE Perusahaan Properti dan Real Estate yang Terdaftar di Bursa Efek Indonesia tahun 2010-2014. Perbanas Review Volume 1, No. 1. November 2015.

[42] Salvatore, Dominick. 2005. Ekonomi Manajerial dalam Perekonomian Global. Salemba Empat: Jakarta.

[43] Sanusi, Anwar. 2016. Metodologi Penelitian Bisnis. Jakarta: Salemba Empat.

[44] Sari, Nurvita. 2017. Pengaruh Struktur Modal Dan Kebijakan Hutang Terhadap

Nilai Perusahaan Pada Perusahaan Manufaktur Sektor Tekstil Dan Garmen Periode 2010-2014 Di Bursa Efek Indonesia. JOM FISIP Vo. 4 No. 2. Oktober 2017.

[45] Sartono, Agus. 2010. Manajemen Keuangan Teori dan Aplikasi. Yogyakarta: BPFE. [46] Sarwono, Jonathan. 2011. Mengenal Path Analysis: Sejarah, Pengertian dan Aplikasi. Jurnal Ilmiah Manajemen Bisnis. Vol. 11, No. 2 November 2011: 285296.

[47] Sarwono J dan Suhayati E. 2010. Riset Akuntasi Menggunakan SPSS, Graha Ilmu, Bandung.

[48] Shin, Hyun-Han dan Rene M. Stulz. 2000. Firm Value, Risk, and Growth Opportunities. NBER Working Paper No. w7808.

[49] Sinambela, L. Poltak. 2014. Metodologi Penelitian Kuantitatif; Untuk Bidang Ilmu Administrasi, Kebijakan Publik, ekonomi, Sosiologi, Komunikasi dan Ilmu Sosial Lainnya. Yogyakarta: Graha Ilmu. 
[50] Soliha dan Taswan, 2002, Pengaruh Kebijakan Hutang Terhadap Nilai Perusahaan Serta Beberapa Faktor Yang Mempengaruhinya. Jurnal Bisnis dan Ekonomi, STIE Stikubank Semarang.

[51] Stulz, Rene M. 1990. Managerial Discretion and Optimal Financing Policies. Journal of Finance Economics, Volume 26, Issue 1, July 1990, Pages 3-27.

[52] Suastini, Ni Made, Ida Bagus Anom Purbawangsa dan Henny Rahyuda. 2016. Pengaruh Kepemilikan Manajerial dan Pertumbuhan Perusahaan terhadap Nilai Perusahaan pada Perusahaan Manufaktur di Bursa Efek Indonesia (Struktur Modal sebagai Variabel Moderasi). E-Jurnal Ekonomi dan Bisnis Universitas Udayana 5.1. Hal. $\quad$ 143-172.

[53] Sudarmadji, Murdoko, dan Sularto. 2007. Pengaruh Ukuran Perusahaaan, Profitabilitas, Leverage, dan Tipe Kepemilikan terhadap Voluntary Disclosure Laporan Keuangan Tahunan. Proceeding PESAT, vol. 2, 21-22 Agustus 2007. Auditorium Kampus Gunadarma.

[54] Syardiana, Gita, dkk. 2015. Pengaruh Investment Opportunity Set, Struktur Modal, Pertumbuhan Perusahaan, dan Return On Asset terhadap Nilai Perusahaan. AKUNTABILITAS Vol. VIII No. 1, April 2015.

[55] Tandi, Tommy, dan Untu. 2018. Pengaruh Struktur Modal dan Pertumbuhan Aset terhadap Profitabilitas Perusahaan Otomotif yang Terdaftar di BEI periode 20132016. Jurnal EMBA, Vol. 6 No. 2, Hal.629-637, April 2018.

[56] Taswan. 2003. Analisis Pengaruh Insider Ownership, Kebijakan Hutang Dan Deviden Terhadap Nilai Perusahaan Serta Faktor-Faktor Yang Mempengaruhinya, Jurnal Bisnis Dan Ekonomi, Vol.10 No.2.

[57] Wardhana, Aditya. 2011. Analisis Pengaruh Debt to Equity Ratio, Profit Margin on Sales, Total Asset Turnover, Institutional Ownership dan Insider Ownership terhadap Return On Equity (Studi Perbandingan pada Perusahaan Non Keuangan yang Masuk LQ45 dan Perusahaan Non Keuangan yang Tidak Masuk LQ45 di Bursa Efek Indonesia periode tahun 2006-2008). Jurnal Bisnis Strategi, Vol. 20 No. 2, Desember 2011. 
[58] Widayanthi dan Sudiartha. 2018. Pengaruh Tingkat Pertumbuhan terhadap Nilai Perusahaan dengan Struktur Modal sebagai Variabel Moderasi. E-Jurnal Manajemen Unud, Vol. 7, No. 4, 2018: 2196-2225.

[59] Widarjono, A. 2016. Ekonometrika Pengantar dan Aplikasinya Disertai Panduan Eviews. Yogyakarta: UPP STIM YKPN.

[60] Wira, Desmond. 2015. Analisis Fundamental Saham Edisi Kedua. Jakarta: Exceed.

[61] Wirawati. 2008. Pengaruh Faktor Fundamental Terhadap Price Book Value Dalam Penilaian Saham DI Bursa Efek Jakarta Dalam Kondisi Krisis Moneter. Buletin Studi Ekonomi Volume 13 No.1.

[62] Yuanita, Missy, Budiyanto dan Slamet. 2016. Influence of Capital Structure, Size and Growth on Profitability and Corporate Value. International Journal of Business and Finance Management Research, IJBFMR.

[63] Yuliana, Fira. 2014. Analisis Pertumbuhan Aset dan Struktu Modal yang Mempengaruhi Profitabilitas Perusahaan (Studi Kasus pada Perusahaan Semen yang Terdaftar Bursa Efek Indonesia). Jurnal Ekonomi dan Keuangan.

[64] Yuniasih, Ni Wayan dan Made Gede Wirakusuma. 2009. Pengaruh Kinerja Keuangan terhadap Nilai Perusahaan dengan Pengungkapan Corporate Social Responsibility dan Good Corporate Governance sebagai Variabel Pemoderasi. Jurnal Ilmiah Akuntansi dan Bisnis, Vol. 4, No. 1.

[65] Yusuf, A. Muri. 2015. Metode Penelitian Kuantitatif, Kualitatif, dan Penelitian Gabungan. Jakarta: Prenadamedia Group. 